\title{
Effect of Niobium Addition on Microstructure and Mechanical Properties of Fe-7Al-0.35C Low-Density Steel
}

\author{
Shivkumar Khaple ${ }^{1,3} \cdot$ Ujjwal Prakash $^{2} \cdot$ Brahma Raju Golla $^{3} \cdot$ V. V. Satya Prasad ${ }^{1}$
}

Received: 4 March 2019 / Accepted: 5 February 2020 / Published online: 18 February 2020

(c) ASM International 2020

\begin{abstract}
The present work reports the effect of niobium addition on a Fe-7wt.\%Al-0.35wt.\%C-based low-density steel. A hot rolling temperature of $1100{ }^{\circ} \mathrm{C}$ was selected to carry out rolling in the intercritical (ferrite + austenite) region. The phases formed on adding $\mathrm{Nb}$ were predicted by thermodynamic calculations using ThermoCalc. All the alloys exhibited a significant $(20 \%$ or more) tensile elongation. Niobium addition also resulted in a significant increase in strength and hardness of the hot-rolled steel. About $80 \%$ increase in the yield strength is observed as the $\mathrm{Nb}$ content increases from 0.2 to $1.0 \mathrm{wt} \%$. Nb carbides present at rolling temperature resist grain growth and lead to improved mechanical properties. This study demonstrates the advantages of adding $\mathrm{Nb}$ to $\mathrm{Fe}-\mathrm{Al}-\mathrm{C}$-based low-density steels. Earlier attempts to add $\mathrm{Nb}$ to low-density steels resulted in very low ductility. This may be related to their susceptibility to hydrogen embrittlement. Melting of high aluminum lowdensity steels in a controlled atmosphere may lead to a considerable improvement in mechanical properties. Further, it is also important to maintain a high $\mathrm{C} / \mathrm{Nb}$ ratio to avoid the formation of Laves phases.
\end{abstract}

Keywords Low-density steel $\cdot \mathrm{Nb}$ addition $\cdot \mathrm{NbC} \cdot \mathrm{Fe}-\mathrm{Al}-\mathrm{C}-\mathrm{Nb} \cdot$ ThermoCalc $\cdot$ Mechanical properties

\section{Introduction}

The density of steel can be reduced by the addition of aluminum [1-4]. Each wt.\% addition of Al gives about $40 \mathrm{MPa}$ increase in strength by solid solution strengthening [1-5] and a density reduction of about $1.5 \%$ [3-7]. Aluminum addition also leads to an improved corrosion resistance [1, 8]. Because of their low-density, high specific strength, and good corrosion resistance, these steels are considered potential structural materials in thermal power plants and petrochemical industry [1-13]. Reducing the weight of an automobile by $10 \%$ can hike the fuel economy by $6-8 \%$, and therefore, these materials have applications in the automotive industry $[1-4,10,11]$. Further, they may also have potential defense applications [12]. We have earlier reported properties of $\mathrm{Fe}-7 \mathrm{wt} . \% \mathrm{Al}$ alloys with carbon addition $[5,7]$.

Shivkumar Khaple

sikaple@yahoo.com

1 Defence Metallurgical Research Laboratory, Hyderabad, Telangana State, India

2 Indian Institute of Technology Roorkee, Roorkee, India

3 National Institute of Technology Warangal, Warangal, India
Here, we report the effect of $\mathrm{Nb}$ addition on microstructure and mechanical properties of a Fe-7wt.\% Al-0.35wt.\%C alloy (all compositions are in wt.\%). In order to predict the formation of phases on $\mathrm{Nb}$ addition, thermodynamic calculations were performed using ThermoCalc software and compared with the experimental results. Earlier attempts to add $\mathrm{Nb}$ to low-density steels resulted in very low ductility [13-16]. This may be related to their susceptibility to hydrogen embrittlement. All the alloys studied in the present work exhibited significant (20\% or more) tensile elongation. It is suggested that the melting of high aluminum low-density steels in a controlled atmosphere may be necessary to achieve improved mechanical properties.

\section{Experimental Procedure}

High-purity raw materials such as iron, aluminum, graphite, and niobium were used for preparing steel pancakes of desired compositions. Non-consumable DC arc melting process with a thoriated tungsten electrode was used for melting the raw materials. The melting chamber was evacuated to $1 \times 10^{-3}$ mbar and refilled with argon. The process of evacuation and refilling was performed twice. 
During melting, the argon gas pressure was maintained at 600 mbar. The arc was initiated without direct contact between the tungsten electrode and the charge material. A current of 850-900 amperes and voltage of 18-20 V were used during melting. The alloy was cast as a pancake of $100 \mathrm{~mm}$ diameter and $10 \mathrm{~mm}$ thickness in a water-cooled copper crucible. For each composition, the pancake was melted three times with periodic reversal of the pancake top. Pancakes were checked for defects by Gamma-ray radiography using a 5-Curie $\mathrm{Co}_{60}$ radioactive source. The amount of $\mathrm{Al}$ and $\mathrm{Nb}$ present in the pancakes was determined by wet chemical analysis. A Leco CS-444 was used to measure the carbon content. The pancake samples were soaked in a furnace for $1 \mathrm{~h}$ at a temperature of $1100{ }^{\circ} \mathrm{C}$. A Demag rolling mill was used to hot-roll the samples to a sheet of $2 \mathrm{~mm}$ thickness. A reduction of $1 \mathrm{~mm}$ in thickness was given to the samples during each pass. After every three passes, the samples were reheated to $1100{ }^{\circ} \mathrm{C}$.

As-cast as well as hot-rolled samples were polished to $0.5-\mu \mathrm{m}$ finish for microstructural studies. The polished samples were etched with a solution of $33 \% \mathrm{HNO}_{3}+1 \%$ $\mathrm{HF}+33 \% \mathrm{CH}_{3} \mathrm{COOH}+33 \% \mathrm{H}_{2} \mathrm{O}$ by volume for microstructural observation. Both as-polished and etched samples were studied in a Leo 440I scanning electron microscope (SEM). The grain size of hot-rolled alloys was determined from optical micrographs using the linear intercept method. The phases present in polished low-density steel samples were identified by Philips x-ray diffractometer using a monochromatic $\operatorname{CuK} \alpha(\lambda=15.40562 \mathrm{~nm})$ radiation at a scan rate of $1^{\circ} \mathrm{min}^{-1}$. The electron probe microanalysis (EPMA) studies were carried out on polished samples to determine the matrix and precipitate compositions and the distribution of the elements present in the steel. The volume fraction of precipitates present in steels was measured using the Biovis Materials Plus Software on SEM images. The average volume fraction of the precipitates on ten SEM images at different locations of each alloy is reported. Thermodynamic calculations were performed to identify phases present at various temperatures and to study phase transformations in the alloys using TCFE6 database of ThermoCalc software. The density of the hot-rolled alloy sheets was measured based on Archimedes principle using a density measuring kit of Sartorius make. The average of five independent measurements was recorded.

The hardness of metallographic samples was measured in a Leco LV700 Vickers hardness testing machine using a 30-kg load and a dwell time of $0.166 \mathrm{~min}$. Microhardness of individual phases was also measured using an Economet $\mathrm{VH}$
1D microhardness machine with $100 \mathrm{~g}$ load. Tensile tests were carried out at an initial strain rate of $1.6 \times 10^{-5} \mathrm{~min}^{-1}$ using a universal testing machine (Instron 5500R) on samples of hot-rolled sheet conforming to ASTM E-8M. The tensile-tested alloy sample's fracture surfaces were observed in the SEM.

\section{Results}

Chemical compositions of the alloys melted are given in Table 1. Radiography studies confirmed that the pancakes are free from internal cracks and porosity. The density of hot-rolled alloys varies in the range of 7159.68 to $7181.92 \mathrm{~kg} / \mathrm{m}^{3}$. X-ray diffraction revealed the presence of $\mathrm{Fe}_{3} \mathrm{AlC}_{0.5}$ ( $\kappa$-carbide) (Fig. 1) and ferrite $(\alpha)$ in all the samples. The alloys exhibited a dendritic microstructure with

Table 1 Chemical composition of melted alloys

\begin{tabular}{llll}
\hline Steel & \multicolumn{2}{l}{ Steel composition } & \\
\cline { 2 - 4 } & Al, wt.\% & C, wt. $\%$ & Nb, wt.\% \\
\hline S1 & $6.8 \pm 0.2$ & $0.28 \pm 0.02$ & $0.2 \pm 0.04$ \\
S2 & $7.0 \pm 0.2$ & $0.32 \pm 0.01$ & $0.4 \pm 0.05$ \\
S3 & $6.6 \pm 0.3$ & $0.30 \pm 0.01$ & $0.7 \pm 0.05$ \\
S4 & $6.8 \pm 0.1$ & $0.34 \pm 0.02$ & $1.0 \pm 0.06$ \\
\hline
\end{tabular}

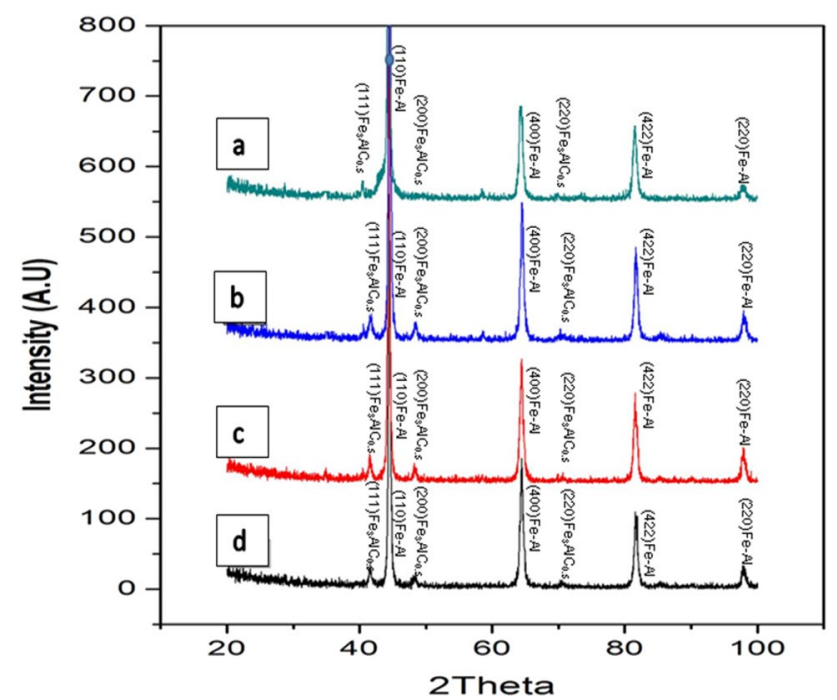

Fig. 1 XRD patterns using $\mathrm{Cu}-\mathrm{k} \alpha$ radiation showing $\mathrm{Fe}-\mathrm{Al}$ and $\mathrm{Fe}_{3} \mathrm{AlC}_{0.5}$ peaks in hot-rolled $\mathrm{Fe}-7 \mathrm{Al}-0.35 \mathrm{C}$ steel with (a) 0.2 , (b) 0.4 , (c) 0.7 , and (d) $1.0 \mathrm{wt} . \%$ niobium 

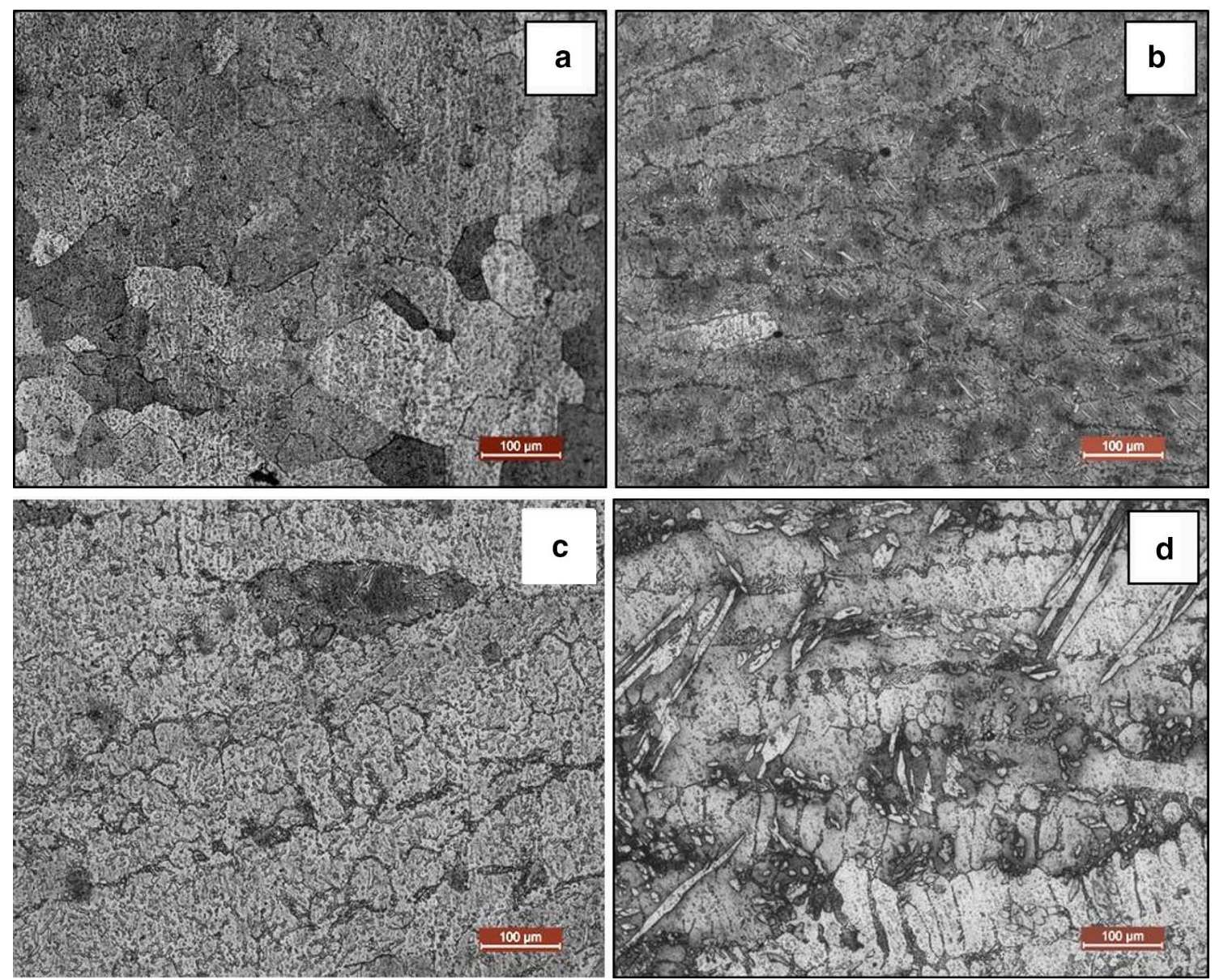

Fig. 2 Optical micrographs showing the as-cast microstructure of Fe-7Al-0.35C steel with (a) 0.2, (b) 0.4, (c) 0.7 , and (d) 1.0 wt.\% niobium

a significant amount of precipitates (Fig. 2). Two types of precipitates (gray and bright) are observed (Fig. 3). As the niobium content increases, the volume fraction of the bright precipitates increases. The bright phase is rich in $\mathrm{Nb}$ and $\mathrm{C}$. The gray phase is identified as $\mathrm{Fe}_{3} \mathrm{AlC}_{0.5}$. In alloys containing up to $0.7 \mathrm{wt} . \% \mathrm{Nb}$, the backscattered electron (BSE) SEM micrographs reveal globular bright precipitates. In the $1 \mathrm{wt} . \% \mathrm{Nb}$ alloy, thin needle-shaped bright precipitates are observed.

Figure 4 shows an equilibrium phase diagram of $\mathrm{Fe}-7 \mathrm{Al}-0.35 \mathrm{C}$ varying $\mathrm{Nb}$ content predicted using ThermoCalc software. The various phases and their amounts present in these steels containing 0 to $1 \mathrm{wt}$. $\%$ niobium at different temperature as calculated by using ThermoCalc are shown in Fig. 5a-e. The solidification of the alloy starts at $1484{ }^{\circ} \mathrm{C}$. The $\mathrm{NbC}$ precipitation may start from the liquid, while the $\kappa$-carbide $\left(\mathrm{Fe}_{3} \mathrm{AlC}_{0.5}\right)$ forms at $812{ }^{\circ} \mathrm{C}$. Based on the $\mathrm{Nb}$ content, the $\mathrm{NbC}$ formation temperature changes and for the content 0.2 to $1 \mathrm{wt} . \%$ of $\mathrm{Nb}$, the $\mathrm{NbC}$ formation temperature is in the range of 1430 to $1462{ }^{\circ} \mathrm{C}$. The austenite phase is observed between 1410 and $810{ }^{\circ} \mathrm{C}$. At room temperature ferrite $(\alpha), \kappa$-carbide and $\mathrm{NbC}$ precipitates are the stable phases. Since the solubility of $\mathrm{NbC}$ is high in austenite [17, 18], further $\mathrm{NbC}$ precipitation occurs during the transformation from austenite to ferrite. From Fig. 4, we can see that the eutectic 
Fig. 3 Backscattered electron micrographs showing the microstructure of as-cast $\mathrm{Fe}-7 \mathrm{Al}-$ $0.35 \mathrm{C}$ steel with (a) 0.2 , (b) 0.4 , (c) 0.7 , and (d) $1.0 \mathrm{wt} . \%$ niobium
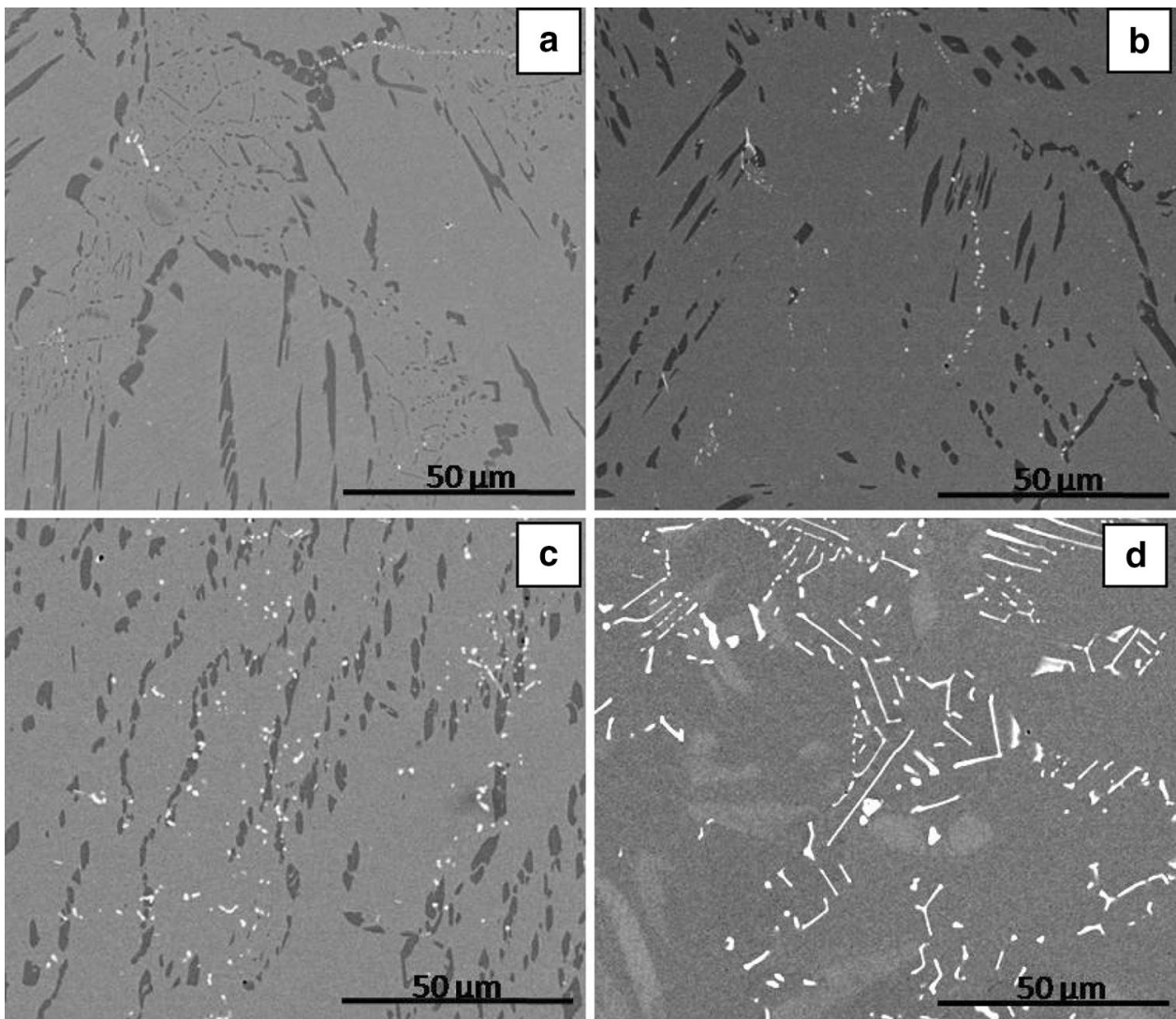

occurs at 0.083 wt. $\%$ of $\mathrm{Nb}$ at $1405{ }^{\circ} \mathrm{C}$ for $\mathrm{Fe}-7 \mathrm{Al}-0.35 \mathrm{C}$ steel. For these steel compositions with $0.083 \mathrm{wt} . \% \mathrm{Nb}$ and above $\mathrm{NbC}$, precipitate formation starts from liquid (Fig. 5). At lower levels of $\mathrm{Nb}(<0.083$ wt.\%), the $\mathrm{NbC}$ precipitate formation starts from austenite. At $1 \mathrm{wt} . \% \mathrm{Nb}$, the niobium carbide formed is very coarse and is in the order of 5-6 $\mu \mathrm{m}$ (Figs. 2d, 3d). Similar observations have been reported for steels containing high carbon and high niobium [18-20].

The pancakes were successfully hot-rolled from 10 to $2 \mathrm{~mm}$ thickness. Figure 6 shows the optical microstructures of the hot-rolled steel samples with different $\mathrm{Nb}$ contents. All samples exhibit partially recrystallized grains. As the $\mathrm{Nb}$ content increases, the average grain size decreases from about 320 to about $80 \mu \mathrm{m}$ (Table 2). The partially recrystallized grains could also be observed in the backscattered electron (BSE) SEM micrographs of the hot-rolled steels (Fig. 7). In the alloy with $1 \% \mathrm{Nb}$, the morphology of $\mathrm{Nb}$ carbides changes from needle to globular after hot rolling. The EPMA analysis of the matrix and precipitates is summarized in Table 2 . No $\mathrm{Nb}$ could be detected in the matrix and gray precipitates. The bright precipitates are found to be enriched in $\mathrm{Nb}$ and $\mathrm{C}$ (Fig. 8). Based on ThermoCalc results, these may be $\mathrm{NbC}$ precipitates. The volume fraction of both these precipitates is given in Table 3. The results (Table 3) show that the volume fraction of $\mathrm{NbC}$ is very small $(<5 \%)$ in all the alloys. Thus, its peaks could not be detected by XRD.

Figure 9 shows engineering stress-strain curves of all the alloys in the hot-rolled condition. The plot of logarithmic stress versus logarithmic plastic strain in the uniform deformation region is shown in Fig. 10. The values of strain hardening exponent ' $n$ ' and strength coefficient ' $k$ ' were determined assuming a power law relationship 
Fig. 4 Equilibrium phase diagram of $\mathrm{Fe}-\mathrm{Al}-\mathrm{C}-\mathrm{Nb}$ with fixed contents of (7\%) $\mathrm{Al}$, $(0.35 \%) \mathrm{C}$ and varying $\mathrm{Nb}$ content as predicted by using ThermoCalc

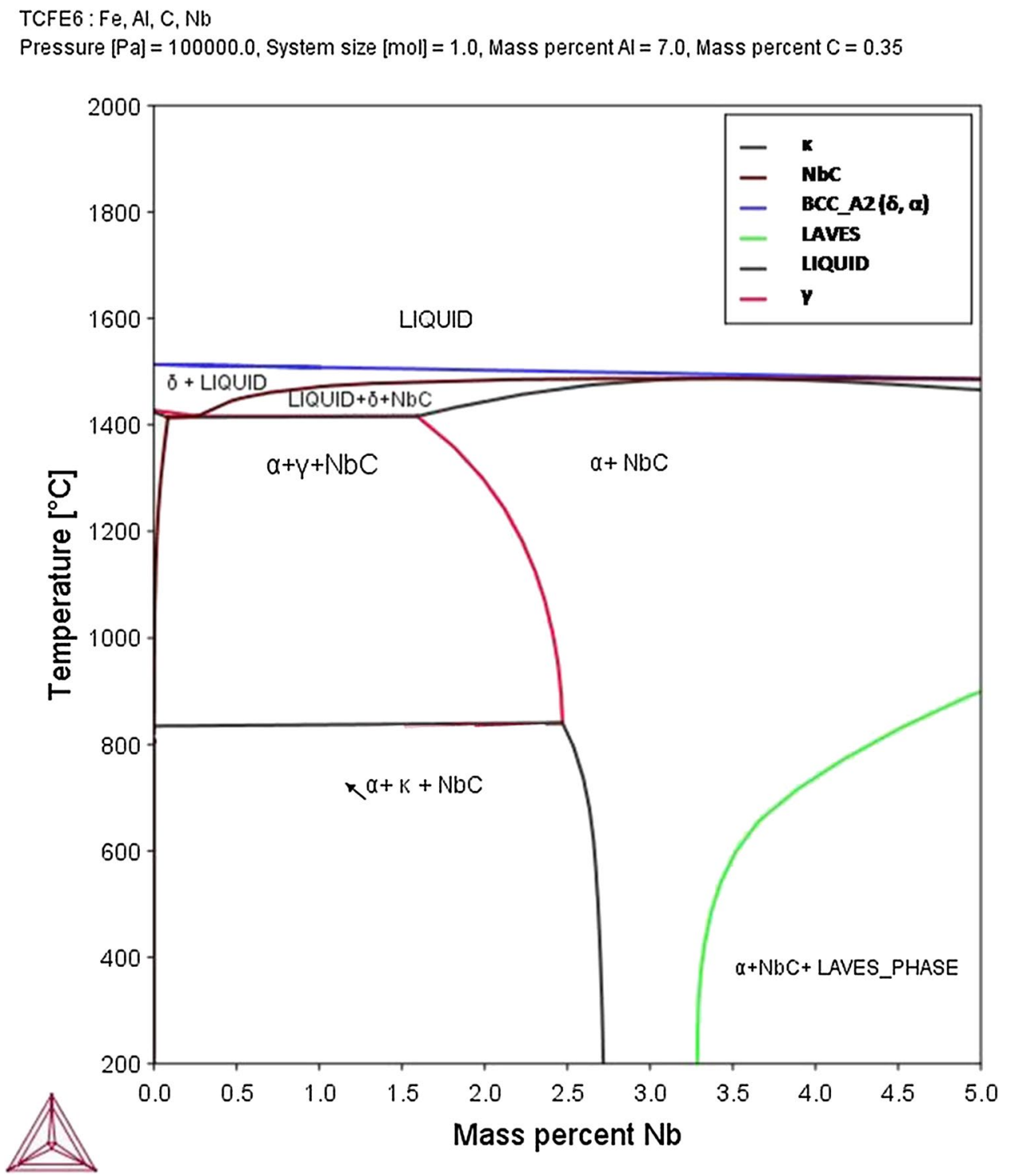

$\left(\sigma=k \varepsilon^{n}\right)$ between logarithmic stress and logarithmic strain. The results are presented in Table 4. The strain hardening exponent remains largely unaffected by $\mathrm{Nb}$ addition; however, the strength coefficient increases from 798 to $1344 \mathrm{MPa}$ (Fig. 10; Table 4). The hardness increases with increase in $\mathrm{Nb}$ content (Table 4). Further, yield strength and tensile strength also increase with the increase in $\mathrm{Nb}$ content (Fig. 9; Table 5). A significant increase (about $80 \%$ ) in the yield strength is evident on increasing $\mathrm{Nb}$ content from $408 \mathrm{MPa}$ at $0.2 \mathrm{wt} \% \mathrm{Nb}$ to $735 \mathrm{MPa}$ at $1.0 \mathrm{wt} . \% \mathrm{Nb}$. This is accompanied by a decrease in tensile elongation from 30 to $20 \%$. The $0.2 \mathrm{wt} \% \mathrm{Nb}$ alloy exhibited cleavage failure, while the alloys with higher $\mathrm{Nb}$ content exhibited mixed mode features comprising transgranular cleavage and ductile dimples (Fig. 11). 
Fig. 5 Amount of various phases in $\mathrm{Fe}-7 \mathrm{Al}-0.35 \mathrm{C}$ steel as a function of temperature as predicted by ThermoCalc with (a) 0 , (b) 0.2, (c) 0.4 (d) 0.7, and (e) 1.0 wt.\% niobium
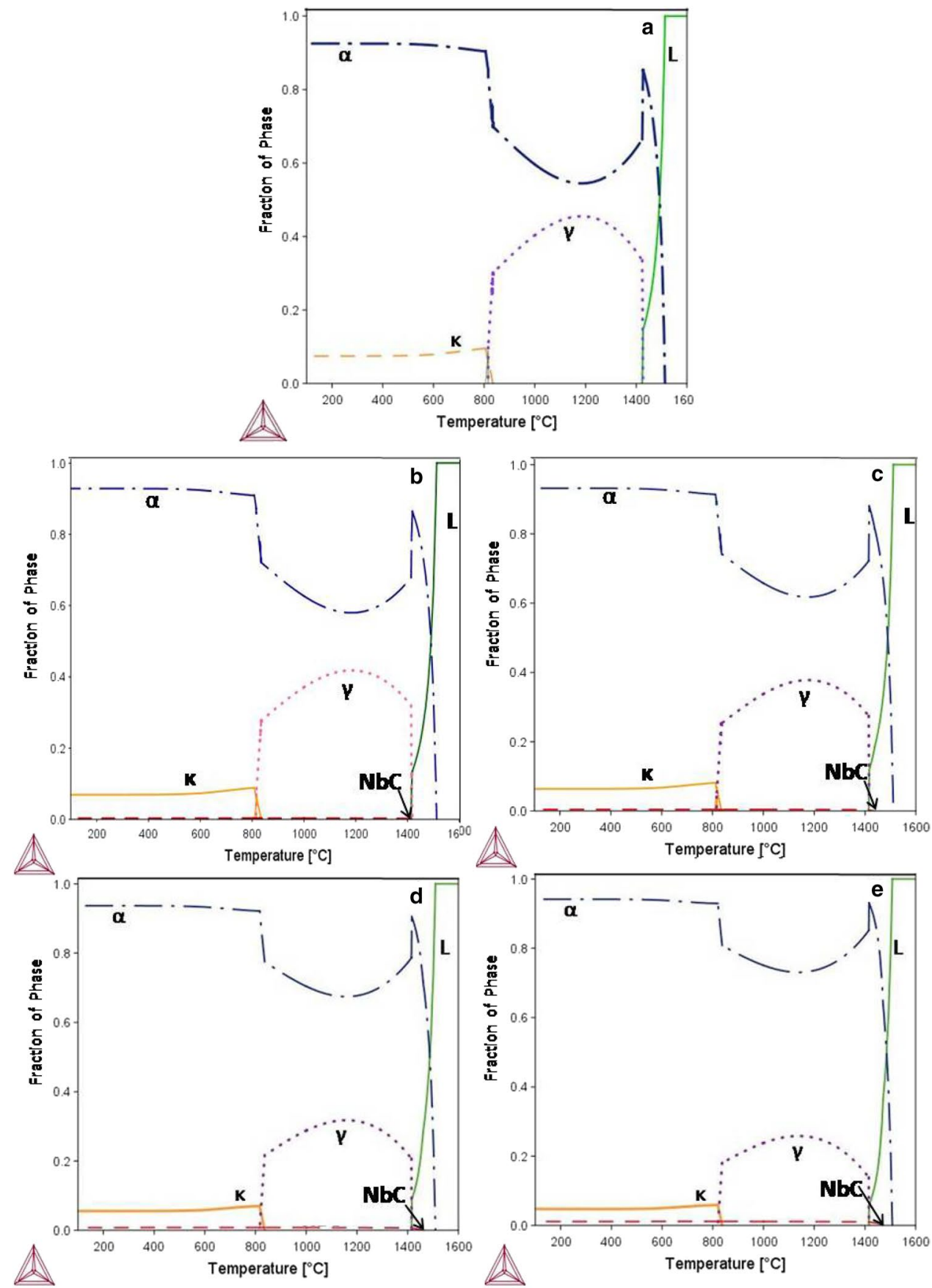

\section{Discussion}

A microstructure consisting of niobium carbide and Laves phases in the ferrite matrix has been reported for Fe-(7.8 to $8.5 \mathrm{Al}$ ) alloy containing different carbon and niobium [13, 14]. The presence of Laves phases is highly detrimental as it can lead to a loss in ductility. In the present study, no Laves phases are observed. This may be ascribed to the much higher $\mathrm{C} / \mathrm{Nb}$ ratio maintained in the present study (1.75 to $0.35)$ as compared to value (0.06) reported in the literature $[13,14]$. At room temperature, the type of the phases (ferrite $(\alpha), \kappa$-carbide and $\mathrm{NbC}$ precipitates) predicted by the ThermoCalc (Fig. 5) agrees well with the type of phases from the experimental results (Fig. 8; Tables 2, 3). The volume fraction of the precipitates formation predicted by phase diagram is low compared to the volume fraction measured from micrographs (Table 3). The reason for the difference may be that the ThermoCalc database is not updated completely. Nevertheless, it is following a similar trend. Phases formed on $\mathrm{Ti}$ additions to $\mathrm{Fe}-7 \mathrm{Al}-0.35 \mathrm{C}$ alloy have also been successfully predicted [21] using ThermoCalc. 
The alloys in the present work could easily be hot-rolled without any cracking. In contrast, $\mathrm{Fe}-\mathrm{Mn}-\mathrm{Al}-\mathrm{C}$ alloys with similar $\mathrm{Al}$ and $\mathrm{C}$ contents have been reported to crack on hot rolling [22-24]. This may be due to intermediate heating of samples after every three passes during rolling practiced in the present work. This practice also ensures a more homogeneous microstructure and avoids the significant banding reported in earlier works [22-24].

The microstructure is significantly refined on hot working (Figs. 6, 7). As the niobium content increases, the ferrite grain size in the hot-rolled steels decreases significantly. This is because of the formation of fine niobium carbides at the ferrite boundaries. The rolling temperature of $1100{ }^{\circ} \mathrm{C}$ was in the intercritical (ferrite + austenite) region [24-26] where the dissolution of $\kappa$-carbides as well as part of $\mathrm{NbC}$ takes place in the austenite. This agrees well with the prediction of phases from the equilibrium diagram calculated by ThermoCalc (Figs. 4, 5). This is also supported by the reported stability of niobium carbides above $1200{ }^{\circ} \mathrm{C}[27$, 28]. In conventional steels, dynamic recrystallization of austenite is delayed by the addition of strong carbide formers such as $\mathrm{Nb}[29,30]$. On similar lines, the addition of niobium to $\mathrm{Fe}-7 \mathrm{Al}-0.35 \mathrm{C}$ may be expected to retard dynamic recrystallization in the present low-density steels during hot rolling. As discussed above, the precipitation of $\mathrm{NbC}$ occurs well above the hot rolling temperature. In the case of alloy with $0.2 \mathrm{wt} . \% \mathrm{Nb}$, the low volume fraction $(0.86 \%)$ of $\mathrm{NbC}$ particles has resulted in coarse grain size $(320 \mu \mathrm{m})$. This is attributed to the insufficient number of $\mathrm{NbC}$ particles present. As the $\mathrm{Nb}$ content is increased to $1 \mathrm{wt} . \%$, there is a fourfold increase in the volume fraction (to $3.42 \%$ ) of $\mathrm{NbC}$ precipitates. This restricts grain growth (Fig. 6) leading to fine grain size $(80 \mu \mathrm{m})$. The size of $\mathrm{NbC}$ precipitates is in the range of 0.3 to $6 \mu \mathrm{m}$ which may retard the grain growth. The EPMA line scan did not detect niobium in the matrix or in the $\kappa$-carbide precipitates. As the $\mathrm{Nb}$ content increases, more carbon is consumed in the formation of niobium carbide and subsequently volume fraction of the perovskite carbide decreases (Table 3).

The density of the alloys varies in the range of 7159.68 to $7181.92 \mathrm{~kg} / \mathrm{m}^{3}$. These low-density steels show a reduction in density of $\sim 10 \%$ compared to the conventional steel $\left(7874.0 \mathrm{~kg} / \mathrm{m}^{3}\right)$. Both strength and hardness increase with an increase in niobium content. This may be attributed to the increase in the volume fraction of fine and hard niobium carbide precipitates and the resulting grain refinement. The increase in the yield strength is almost $80 \%$ as we increase the $\mathrm{Nb}$ content from 0.2 to $1 \mathrm{wt} . \%$. At the same time, there is a decrease in ductility from 30 to $20 \%$. However, all the alloys exhibited better ductility than $13.5 \%$ tensile elongation reported [5] for hot-rolled $\mathrm{Nb}$ free steel with similar $\mathrm{Al}$ and $\mathrm{C}$ content. The strain hardening exponent observed in the present work is $\sim 0.15$ (Table 4 ). The drop in $n$ value with an increase in $\mathrm{Nb}$ content is very marginal despite the increase in strength. This may allow good formability of the steel for various operations like deep drawing, bending, etc.

The tensile test results of the present work are compared with those reported for the $\mathrm{Fe}-\mathrm{Al}$-based alloys containing different carbon and niobium levels (Table 5). It can be observed that steels containing higher aluminum (8.5 and $10.5 \mathrm{wt} . \%$ ) with carbon and different niobium contents have shown high strength but poor ductility $[14,15]$. This may be because these steels are prone to environmental embrittlement due to the presence of $\mathrm{Al}[5,9,31]$. The reduced ductility may also be attributed to the ordering effect $[3,5,9$, 10]. The $\mathrm{Fe}-7 \% \mathrm{Al}-0.35 \% \mathrm{C}$ alloy processed by air induction melting under flux cover has been reported to have exhibited only $13.5 \%$ elongation [5]. The improved mechanical properties obtained in the present work are also attributed to the use of a controlled atmosphere during melting. It has also been demonstrated that a range of tensile properties is attainable by varying niobium content to $\mathrm{Fe}-7 \mathrm{Al}-0.35 \mathrm{C}$ steel. Use of controlled atmosphere appears critical from the present results. Melting process such as vacuum induction melting and vacuum arc melting are well established industrially and hence can be practiced for producing low-density steels containing carbon and niobium on a tonnage scale.

It is well known that coarse-grained ferritic steels mainly fracture by cleavage [32]. The resistance to cleavage is mainly provided by grain boundaries $[32,33]$. Stress at the crack tip increases with the reciprocal root of the grain diameter. The plastic strain needed for fracture of a grain increases with decreasing grain size. This may be explained by a large number of dislocation pileup at a grain boundary which leads to coarse cleavage fracture [32]. This is observed in the steel with 0.2 wt.\% Nb (Fig. 11a). A mixed mode fracture surface is exhibited by the alloys with 0.4 to $1 \mathrm{wt} . \% \mathrm{Nb}$ which consists of finer dimples and shorter cleavage steps (Fig. 11b-d). This is attributed to the finer grain size displayed by the alloy with higher $\mathrm{Nb}$ content (Fig. 6; Table 2). Further, a large number of fine precipitates ( $\mathrm{NbC}$ and $\kappa$-carbides) effectively reduce the dislocation pileup 

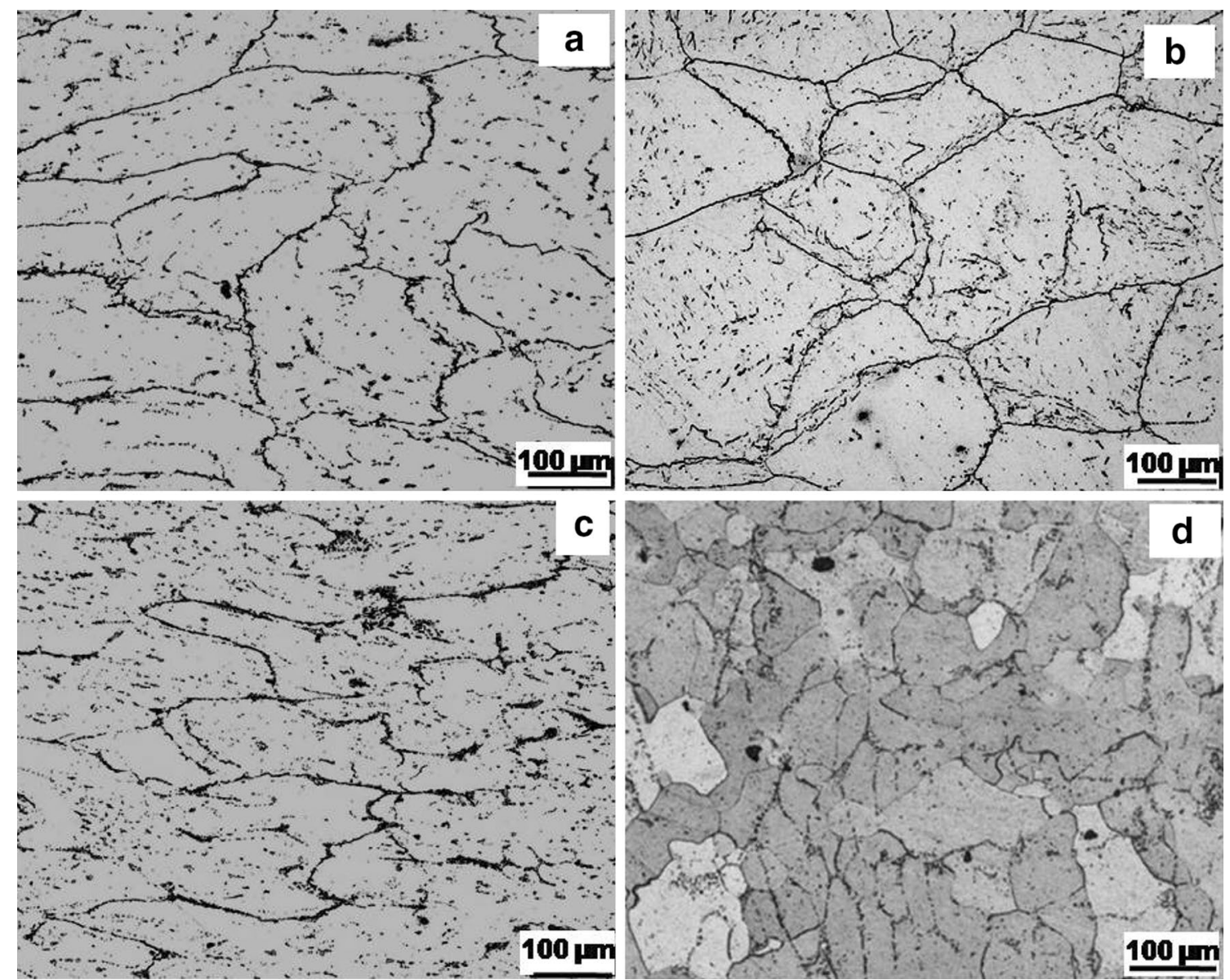

Fig. 6 Optical micrographs showing the microstructure of hot-rolled Fe-7Al-0.35C steel with (a) 0.2, (b) 0.4, (c) 0.7, and (d) 1.0 wt.\% niobium

Table 2 Grain size and microanalysis (EPMA) of phases present in hot-rolled alloys

\begin{tabular}{|c|c|c|c|c|c|c|}
\hline Steel & Nominal composition, wt.\% & $\begin{array}{l}\text { Average grain } \\
\text { size, } \mu \mathrm{m}\end{array}$ & Elements & Matrix, wt.\% & $\begin{array}{l}\text { Precipitate } 1 \text { (gray), } \\
\text { wt. } \%\left(\mathrm{Fe}_{3} \mathrm{AlC}_{0.5}\right)\end{array}$ & $\begin{array}{l}\text { Precipitate } 2 \text { (white), } \\
\text { wt.\% (niobium car- } \\
\text { bide) }\end{array}$ \\
\hline \multirow[t]{4}{*}{ S1 } & \multirow[t]{4}{*}{$\mathrm{Fe}-7 \mathrm{Al}-0.35 \mathrm{C}-0.2 \mathrm{Nb}$} & \multirow{4}{*}{$320 \pm 15.6$} & $\mathrm{Fe}$ & 93.10 & 82.10 & 3.98 \\
\hline & & & $\mathrm{Al}$ & 6.90 & 14.30 & $\ldots$ \\
\hline & & & $\mathrm{C}$ & $\ldots$ & 3.60 & 10.84 \\
\hline & & & $\mathrm{Nb}$ & $\ldots$ & $\ldots$ & 85.06 \\
\hline \multirow[t]{4}{*}{$\mathrm{S} 2$} & \multirow[t]{4}{*}{$\mathrm{Fe}-7 \mathrm{Al}-0.35 \mathrm{C}-0.4 \mathrm{Nb}$} & \multirow[t]{4}{*}{$280 \pm 7.6$} & $\mathrm{Fe}$ & 92.80 & 82.10 & 3.12 \\
\hline & & & $\mathrm{Al}$ & 7.20 & 14.52 & $\ldots$ \\
\hline & & & $\mathrm{C}$ & $\ldots$ & 3.48 & 10.98 \\
\hline & & & $\mathrm{Nb}$ & $\ldots$ & $\ldots$ & 85.90 \\
\hline \multirow[t]{4}{*}{$\mathrm{S} 3$} & \multirow[t]{4}{*}{$\mathrm{Fe}-7 \mathrm{Al}-0.35 \mathrm{C}-0.7 \mathrm{Nb}$} & \multirow[t]{4}{*}{$140 \pm 7.6$} & $\mathrm{Fe}$ & 93.38 & 82.04 & 2.82 \\
\hline & & & $\mathrm{Al}$ & 6.62 & 14.70 & $\ldots$ \\
\hline & & & $\mathrm{C}$ & $\ldots$ & 03.26 & 11.06 \\
\hline & & & $\mathrm{Nb}$ & $\ldots$ & $\ldots$ & 86.12 \\
\hline \multirow[t]{4}{*}{ S4 } & \multirow[t]{4}{*}{$\mathrm{Fe}-7 \mathrm{Al}-0.35 \mathrm{C}-1.0 \mathrm{Nb}$} & \multirow[t]{4}{*}{$80 \pm 4.4$} & $\mathrm{Fe}$ & 93.17 & 82.00 & 2.21 \\
\hline & & & $\mathrm{Al}$ & 6.83 & 14.80 & $\cdots$ \\
\hline & & & $\mathrm{C}$ & $\ldots$ & 03.20 & 11.43 \\
\hline & & & $\mathrm{Nb}$ & $\ldots$ & $\ldots$ & 87.16 \\
\hline
\end{tabular}



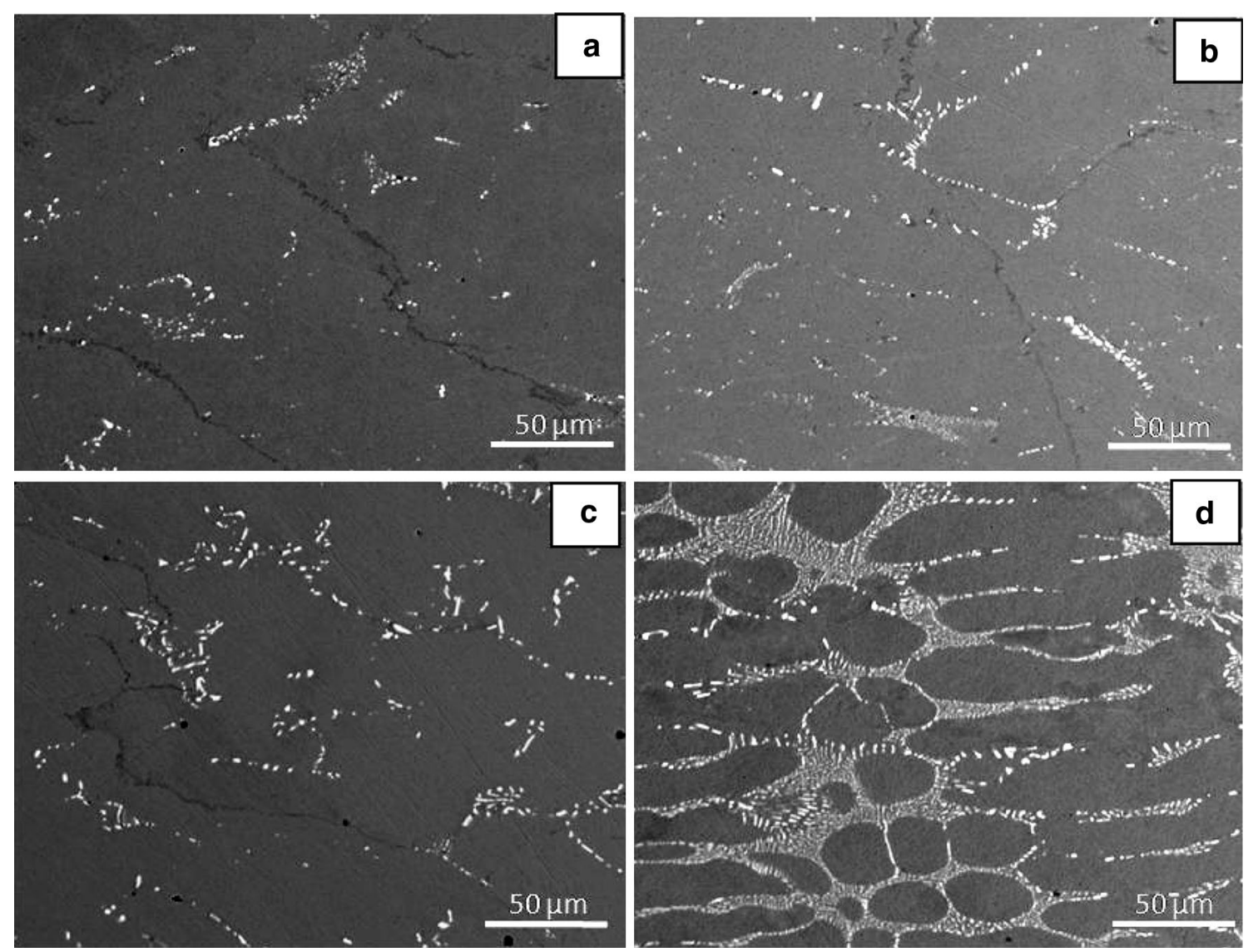

Fig. 7 BSE micrographs of hot-rolled $\mathrm{Fe}-7 \mathrm{Al}-0.35 \mathrm{C}$ steel showing the distribution of precipitates (bright ones are rich in $\mathrm{Nb}$ and $\mathrm{C}$, and gray ones are $\mathrm{Fe}_{3} \mathrm{AlC}_{0.5}$ precipitates) with (a) 0.2 and (b) 0.4 , (c) 0.7, and (d) $1.0 \mathrm{wt} \%$ niobium

length, thereby reducing the size of the cleavage steps. Though the $0.2 \mathrm{wt} . \% \mathrm{Nb}$ steel exhibited cleavage failure (Fig. 11a), it exhibits adequate ductility (30\%). The volume fraction of hard niobium carbide increases with $\mathrm{Nb}$ content (Table 3), which leads to the reduction in ductility from 30 to $20 \%$.

\section{Conclusions}

1. The Fe-7Al-0.35C-based low-density steels containing $0.2 \%$ to $1 \%$ niobium could be successfully hot-rolled without showing any evidence of cracking or band for- mation. After $80 \%$ reduction, all the samples exhibited partially recrystallized grains.

2. The alloys exhibited a ferritic matrix $(\alpha)$ containing $\mathrm{Fe}_{3} \mathrm{AlC}_{0.5}$ ( $\kappa$-carbide) and $\mathrm{NbC}$. The volume fraction of $\mathrm{NbC}$ precipitates increases with an increase in niobium content. The phases predicted using ThermoCalc agree well with the experimental results.

3. A significant increase in strength and hardness is observed on increasing $\mathrm{Nb}$ content. This is attributed to the cumulative contribution from the increase in the volume fraction of the fine $\mathrm{NbC}$ carbides and the resulting grain refinement. All the compositions exhibit significant ( $>20 \%$ ) tensile elongation. 
Fig. 8 BSE image and line scan of EPMA observed for the elements present in the bright precipitate and matrix of hot-rolled $\mathrm{Fe}-7 \mathrm{Al}-0.35 \mathrm{C}$ with 0.7 wt. $\%$ niobium

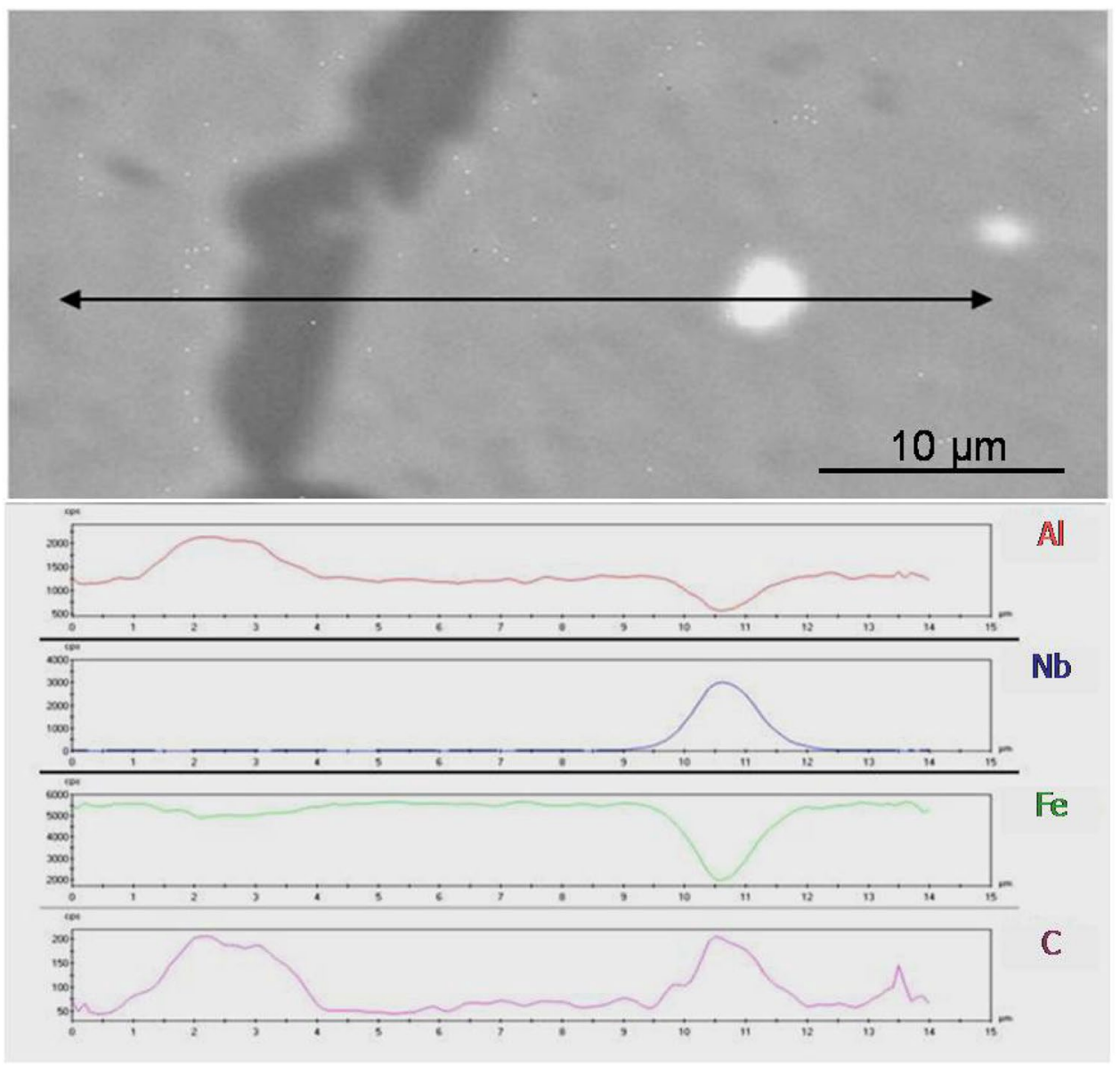

Table 3 Volume fraction of phases present in hot-rolled alloys

\begin{tabular}{|c|c|c|c|c|c|c|}
\hline \multirow[t]{3}{*}{ Sl. no. } & \multirow[t]{3}{*}{ Nominal steel composition, wt.\% } & \multicolumn{5}{|c|}{ Volume fraction of phases, $\%$} \\
\hline & & \multicolumn{2}{|c|}{ Predicted by ThermoCalc } & \multicolumn{3}{|c|}{ Measured using image analyzer } \\
\hline & & $\begin{array}{l}\mathrm{Fe}_{3} \mathrm{AlC}_{0.5}(\kappa \mathrm{car}- \\
\text { bide }) \text { precipitate }\end{array}$ & $\begin{array}{l}\text { Niobium car- } \\
\text { bide precipitate }\end{array}$ & $\begin{array}{l}\mathrm{Fe}_{3} \mathrm{AlC}_{0.5}(\kappa \text { car- } \\
\text { bide) precipitate }\end{array}$ & $\begin{array}{l}\text { Niobium car- } \\
\text { bide precipitate }\end{array}$ & $\alpha \mathrm{Fe}-\mathrm{Al}$ (matrix) \\
\hline $\mathrm{S} 1$ & $\mathrm{Fe}-7 \mathrm{Al}-0.35 \mathrm{C}-0.2 \mathrm{Nb}$ & 11.82 & 0.38 & $13.80 \pm 0.1$ & $0.86 \pm 0.1$ & $86.46 \pm 0.1$ \\
\hline S2 & $\mathrm{Fe}-7 \mathrm{Al}-0.35 \mathrm{C}-0.4 \mathrm{Nb}$ & 10.41 & 0.64 & $12.64 \pm 0.2$ & $1.08 \pm 0.3$ & $86.15 \pm 0.4$ \\
\hline $\mathrm{S} 3$ & $\mathrm{Fe}-7 \mathrm{Al}-0.35 \mathrm{C}-0.7 \mathrm{Nb}$ & 09.83 & 0.88 & $12.32 \pm 0.2$ & $3.04 \pm 0.2$ & $84.84 \pm 0.3$ \\
\hline S4 & $\mathrm{Fe}-7 \mathrm{Al}-0.35 \mathrm{C}-1.0 \mathrm{Nb}$ & 08.07 & 1.86 & $12.04 \pm 0.1$ & $3.42 \pm 0.3$ & $84.62 \pm 0.5$ \\
\hline
\end{tabular}

4. It is also demonstrated that the use of a controlled atmosphere during melting may be necessary due to the presence of $\mathrm{Al}$ in these low-density steels. This may explain the low ductility reported on $\mathrm{Nb}$ addition for these steels. In addition, it is also important to maintain a high $\mathrm{C} / \mathrm{Nb}$ ratio to avoid the formation of Laves phases. 


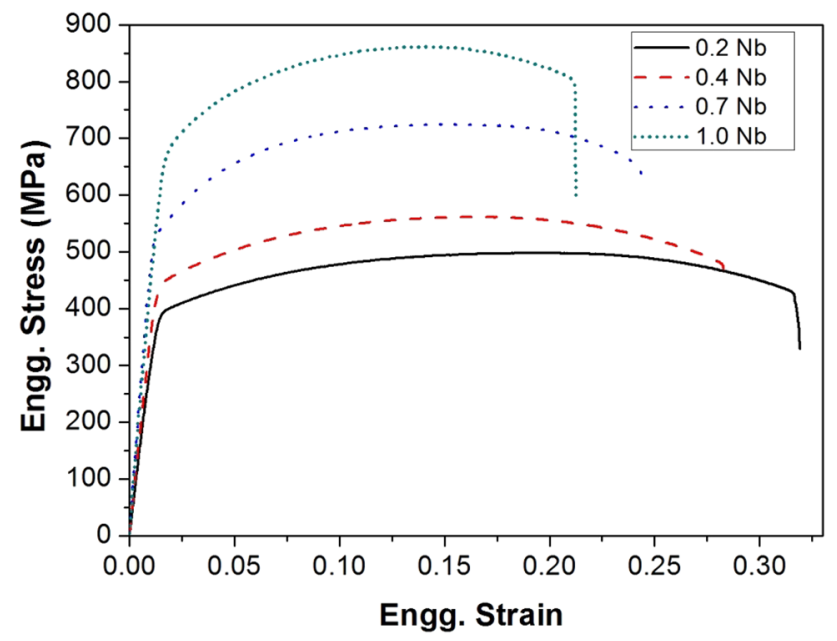

Fig. 9 Engineering stress-strain curves for tensile samples of hotrolled $\mathrm{Fe}-7 \mathrm{Al}-0.35 \mathrm{C}$ steel with different niobium contents

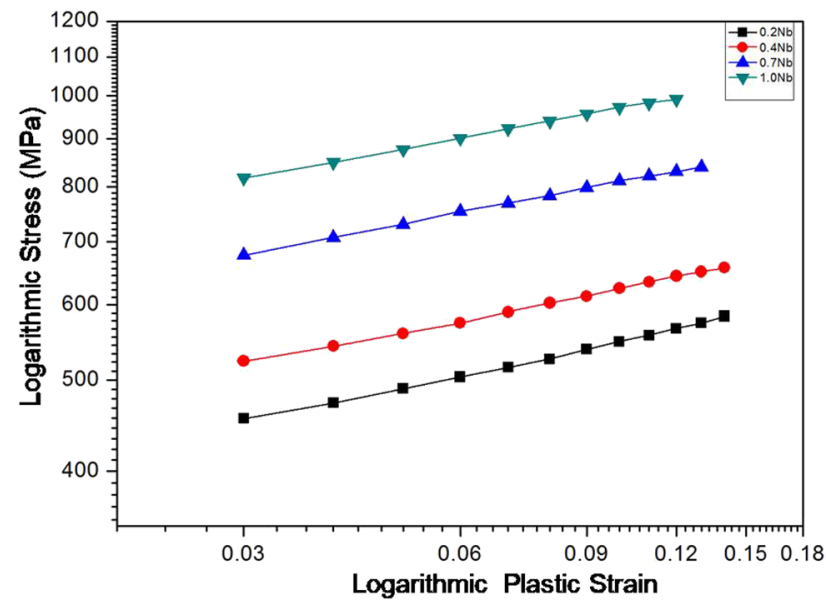

Fig. 10 Plot of logarithmic stress-logarithmic plastic strain curves of hot-rolled $\mathrm{Fe}-7 \mathrm{Al}-0.35 \mathrm{C}$ steel with different niobium contents

Table 4 Variation of bulk hardness, strain hardening exponent, and strength coefficient in hot-rolled alloys

\begin{tabular}{|c|c|c|c|c|}
\hline Steel & $\begin{array}{l}\text { Composition } \\
\mathrm{Nb} \text {, wt. } \%\end{array}$ & $\begin{array}{l}\text { Bulk } \\
\text { hardness } \\
\left(\mathrm{Hv}_{30}\right)\end{array}$ & $\begin{array}{l}\text { Strain harden- } \\
\text { ing exponent } \\
(n)\end{array}$ & $\begin{array}{l}\text { Strength } \\
\text { coefficient } K \text {, } \\
\mathrm{MPa}\end{array}$ \\
\hline $\mathrm{S} 1$ & $\begin{array}{l}\mathrm{Fe}-7 \mathrm{Al}-0.35 \mathrm{C}- \\
\quad 0.2 \mathrm{Nb}\end{array}$ & $246 \pm 10$ & $0.1643 \pm 0.001$ & $798 \pm 1.8$ \\
\hline S2 & $\begin{array}{l}\mathrm{Fe}-7 \mathrm{Al}-0.35 \mathrm{C}- \\
\quad 0.4 \mathrm{Nb}\end{array}$ & $282 \pm 14$ & $0.1547 \pm 0.002$ & $885 \pm 1.6$ \\
\hline S3 & $\begin{array}{l}\mathrm{Fe}-7 \mathrm{Al}-0.35 \mathrm{C}- \\
0.7 \mathrm{Nb}\end{array}$ & $336 \pm 18$ & $0.1472 \pm 0.003$ & $1137 \pm 1.7$ \\
\hline S4 & $\begin{array}{l}\mathrm{Fe}-7 \mathrm{Al}-0.35 \mathrm{C}- \\
\quad 1.0 \mathrm{Nb}\end{array}$ & $402 \pm 22$ & $0.1408 \pm 0.002$ & $1344 \pm 1.5$ \\
\hline
\end{tabular}

The measured microhardness of $\mathrm{Fe}_{3} \mathrm{AlC}_{0.5}$ precipitates: $585 \pm 12$ $\mathrm{Hv}_{0.1}$ and niobium carbide: $2040 \pm 18 \mathrm{Hv}_{0.1}$

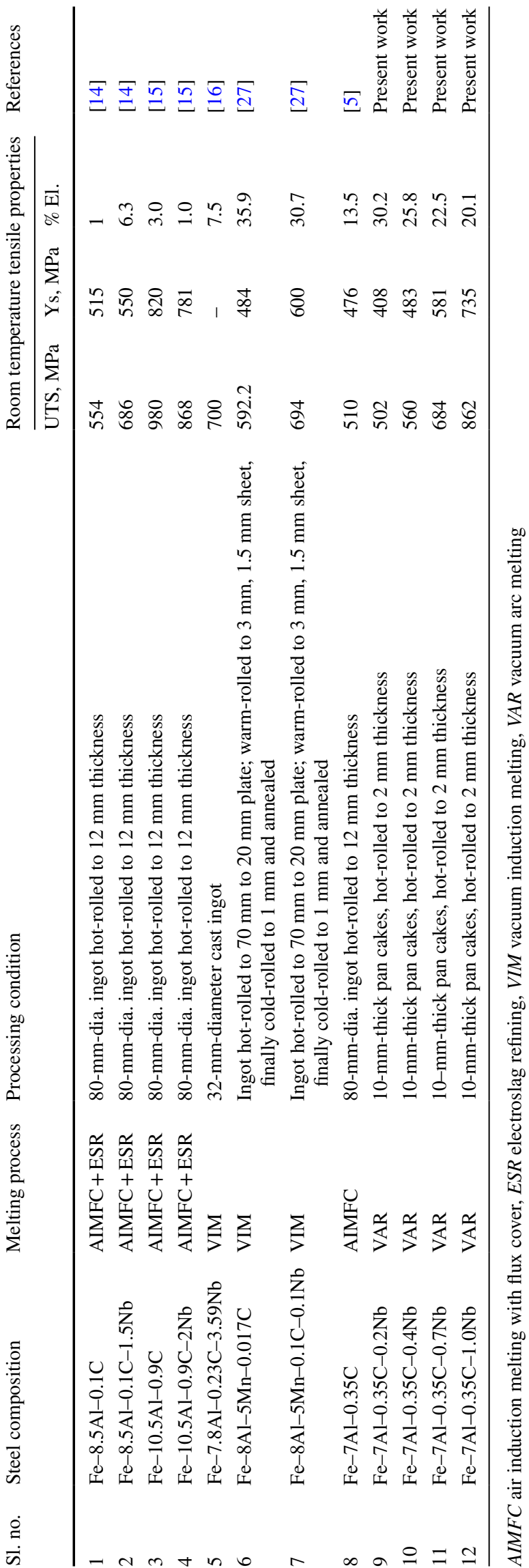


Fig. 11 SEM fractographs of hot-rolled Fe-7Al-0.35C steel showing the cleavage features for (a) 0.2, mixed mode fracture with smaller cleavage length observed for (b) 0.4 , (c) 0.7 , and (d) $1.0 \mathrm{wt} . \%$ niobium
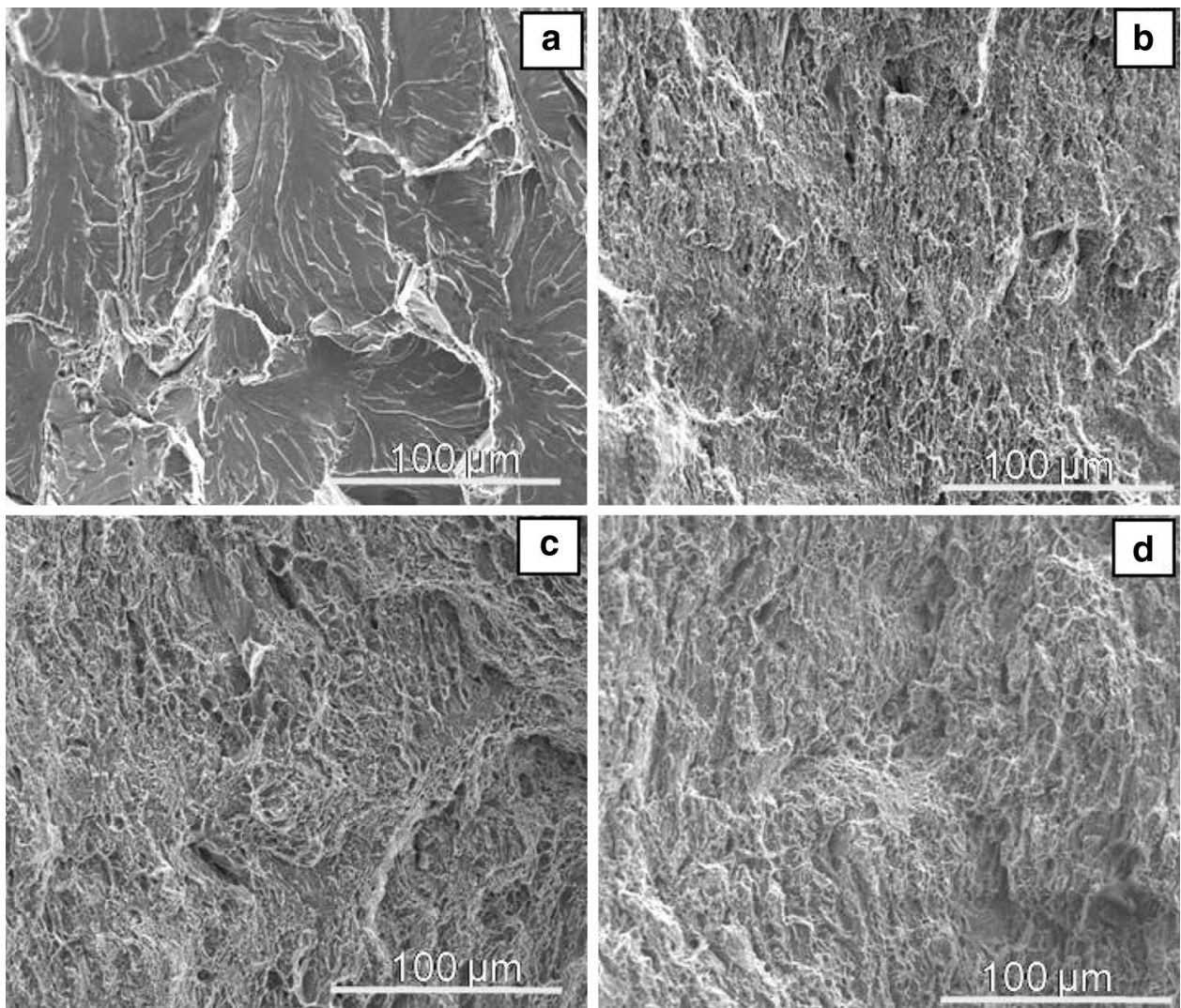

Acknowledgements The authors are grateful to Defence Research and Development Organization, New Delhi, for the financial support.

\section{Compliance with Ethical Standards}

Conflicts of interest The authors declare that there is no conflict of interest.

\section{References}

1. S. Chen, R. Rana, A. Haldar, R.K. Ray, Current state of Fe-MnAl-C low density steels. Prog. Mater. Sci. 89, 345-391 (2017)

2. R. Rana, C. Lahaye, R.K. Ray, Overview of lightweight ferrous materials: strategies and promises. JOM 66(9), 1734-1746 (2014)

3. G. Frommeyer, E.J. Drewes, B. Engl, Physical and mechanical properties of iron-aluminium-(Mn, Si) lightweight steels. La Rev De Métallurgie-CIT 10, 1245-1253 (2000)

4. D.-W. Suh, N.J. Kim, Low-density steels. Scr. Mater. 68(6), 337$338(2013)$

5. V.V. Satya Prasad, S. Khaple, R.G. Baligidad, Melting, processing, and properties of disordered $\mathrm{Fe}-\mathrm{Al}$ and $\mathrm{Fe}-\mathrm{Al}-\mathrm{C}$ based alloys. JOM 66(9), 1785-1793 (2014)

6. R. Rana, C. Liu, R.K. Ray, Low density low carbon $\mathrm{Fe}-\mathrm{Al}$ ferritic steels. Scr. Mater. 68, 354-359 (2013)

7. S. Khaple, R.G. Baligidad, V.V. Satya Prasad, D.V.V. Satyanarayana, Microstructure and mechanical properties of $\mathrm{Fe}-7 \mathrm{Al}$ based lightweight steel containing carbon. Mater. Sci. Technol. 31(12), 1408-1416 (2015)
8. R. Kartikasari, Effect of aluminum content on microstructure and corrosion behavior of as cast $\mathrm{Fe}-\mathrm{Al}-\mathrm{C}$ alloys lightweight steel. Int. J. Appl. Eng. Res. 9(13), 2241-2249 (2014)

9. S. Khaple, R.G. Baligidad, M. Sankar, V.V. Satya Prasad, Effect of melting process and aluminium content on microstructure and mechanical properties of $\mathrm{Fe}-\mathrm{Al}$ alloy. ISIJ Int. 50(10), 1483-1487 (2010)

10. J. Herrmann, G. Inden, G. Sauthoff, Deformation behaviour of iron-rich iron aluminum alloys at low alloys at low temperatures. Acta Mater. 51, 2847-2857 (2003)

11. I. Zuazo, B. Hallstedt, B. Lindahl, M. Selleby, M. Soler, A. Etienne, A. Perlade, D. Hasenpouth, V. Massardier-jourdan, S. Cazottes, X. Kleber, Low-density steels: complex metallurgy for automotive applications. JOM 66(9), 1747-1758 (2014)

12. L. Bartlett, V.D. Aken, High manganese and aluminum steels for the military and transportation industry. JOM 66(91), 1770-1784 (2014)

13. A. Schneider, L. Falat, G. Sauthoff, G. Frommeyer, Constitution and microstructures of $\mathrm{Fe}-\mathrm{Al}-\mathrm{M}-\mathrm{C}-(\mathrm{M}=\mathrm{Ti}, \mathrm{V}, \mathrm{Nb}, \mathrm{Ta})$ alloys with carbides and Laves-phase. Intermetallics 11, 443-450 (2003)

14. R.G. Baligidad, Effect of niobium on microstructure and mechanical properties of hot-rolled $\mathrm{Fe}-8.5 \mathrm{wt} \% \mathrm{Al}-0.1 \mathrm{wt} \% \mathrm{C}$ alloy. J. Mater. Sci. 39, 5599-5602 (2004)

15. R.G. Baligidad, Effect of niobium on microstructure and mechanical properties of high carbon $\mathrm{Fe}-10.5 \mathrm{wt}$ \% Al alloys. Mater. Sci. Eng. A 368, 131-138 (2004)

16. L. Falat, A. Schneider, G. Sauthoff, G. Frommeyer, Mechanical properties of $\mathrm{Fe}-\mathrm{Al}-\mathrm{M}-\mathrm{C}(\mathrm{M}=\mathrm{Ti}, \mathrm{V}, \mathrm{Nb}, \mathrm{Ta})$ alloys with strengthening carbides and Laves phase. Intermetallics 13, 1256$1262(2005)$

17. T. Gladman, The Physical Metallurgy of Microalloyed Steels, $1 \mathrm{st}$ edn. (Maney Publishing, London, 1997), pp. 1-363 
18. J.G. Speer, A.L. Araujo, D.K. Matlock, E. de Moor, Nb-microalloying in next-generation flat-rolled steels: an overview. Mater. Sci. Forum 879, 1834-1840 (2016)

19. A. Ray, Niobium microalloyed rail steels. Mater. Sci. Technol. 33(13), 1-17 (2017)

20. M.D. Hecht, B.A. Webler, Y.N. Picard, Effects of Nb modification and cooling rate on the microstructure in an ultrahigh carbon steel. Metall. Mater. Trans. A 49, 2161-2172 (2018)

21. S. Khaple, V.V. Satya Prasad, B.R. Golla, Microstructural characterisation of $\mathrm{Ti}$ containing $\mathrm{Fe}-7 \mathrm{Al}-0.35 \mathrm{C}$ based low density steel. Trans. Indian Inst. Met. 71(11), 2713-2716 (2018)

22. S.Y. Shin, H. Lee, S.Y. Han, C.-H. Seo, K. Choi, S. Lee, N.J. Kim, J.-H. Kwak, K.-G. Chi, Correlation of microstructure and cracking phenomenon occurring during hot rolling of lightweight steel plates. Metall. Mater. Trans. A 41, 138-148 (2010)

23. S.S. Sohn, B.-J. Lee, S. Lee, J.-H. Kwak, Effects of aluminum content on cracking phenomenon occurring during cold rolling of three ferrite-based lightweight steel. Acta Mater. 61, 56265635 (2013)

24. S.Y. Han, S.Y. Shin, S. Lee, N.J. Kim, J.-H. Kwak, K.-G. Chin, Effect of carbon content on cracking phenomenon occurring during cold rolling of three light-weight steel plates. Metall. Mater. Trans. A 42, 138-146 (2011)

25. M. Palm, G. Inden, Experimental determination of phase equilibria in the $\mathrm{Fe}-\mathrm{Al}-\mathrm{C}$ system. Intermetallics 3, 443-454 (1995)

26. V. Raghavan, Phase Diagrams of Ternary Iron Alloys. Part I (ASM, Metals Park, 1987)

27. A. Zargaran, H.S. Kim, J.H. Kwak, N.J. Kim, Effect of Nb and $\mathrm{C}$ additions on the microstructure and tensile properties of lightweight ferritic Fe-8Al-5Mn alloy. Scr. Mater. 89, 37-40 (2014)

28. A. Zargaran, H.S. Kim, J.H. Kwak, N.J. Kim, Effect of C content on the microstructure and tensile properties of lightweight ferritic Fe-8Al-5Mn-0.1Nb alloy. Met. Mater. Int. 21(1), 79-84 (2015)

29. A.J. Deardo, Niobium in modern steels. Int. Mater. Rev. 48(6), 371-402 (2003)

30. M.G. Akben, I. Weiss, J.J. Jones, Dynamic precipitation and solute hardening in a $\mathrm{V}$ microalloyed steel and two $\mathrm{Nb}$ steels containing high levels of Mn. Acta Metall. 29, 111-121 (1981)

31. V.K. Sikka, S. Viswanathan, S. Vyas, Acceptable aluminum additions for minimal environmental effect in iron aluminides, in High Temperature Ordered Intermetallic Alloys V, vol. 288, ed. by I. Baker, R. Darolia, J.D. Whittenberger, M.H. Yoo (Materials Research Society, Pittsburgh, 1993), pp. 971-976

32. J.H. Chen, R. Cao, Micromechanism of Cleavage Fracture of Metals: A Comprehensive Microphysical Model for Cleavage Cracking in Metals (Elsevier, Amsterdam, 2015)

33. M. Calcagnotto, D. Ponge, Y. Adachi, D. Raabe, Effect of grain refinement on strength and toughness in dual-phase steels, in Proceedings of the 2nd International Symposium on Steel Science (ISSS 2009), Oct 21-24, ed. by K. Higashida, N. Tsuji (The Iron and Steel Institute of Japan, Kyoto, Japan, 2009)

Publisher's Note Springer Nature remains neutral with regard to jurisdictional claims in published maps and institutional affiliations. 